\title{
PENINGKATAN HASIL BELAJAR MENDISKRIPSIKAN PELAKU EKONOMI MASYARAKAT MELALUI METODE INQUIRI PADA SISWA KELAS VIII A SEMESTER 1 SMP NEGERI 7 SUKOHARJO TAHUN 2017/2018
}

\author{
Sri Rejono \\ SMP Negeri 7 Sukoharjo, Jawa Tengah \\ Email: srirejono@gmail.com
}

\begin{abstract}
Abstrak: Penelitian ini bertujuan untuk meningkatkan hasil belajar mendiskripsikan pelaku ekonomi masyarakat melalui metode inquiri pada siswa kelas VIII A SMP Negeri 7 Sukoharjo Semester I Tahun Pelajaran 2017/2018. Metode penelitian menggunakan Penelitian Tindakan Kelas yang dilaksanakan dalam dua siklus setiap siklus terdiri dua kali pertemuan, dengan empat tahap penelitian: perencanaan, pelaksanaan, pengamatan dan refleksi. Subjek penelitian ini adalah siswa-siswi kelas VIII A SMP Negeri 7 Sukoharjo tahun ajaran 2017/2018. Dengan jumlah 32 siswa. Teknik pengumpulan data yang digunakan adalah observasi, wawancara, tes, dan dokumentasi. Analisis data yang digunakan dalam penelitian ini adalah analisis deskriptif kualitatif. Hasil penelitian ini adalah meningkatkan hasil belajar mendiskripsikan pelaku ekonomi masyarakat. Hal ini dibuktikan dengan peningkatan hasil belajar siswa pada siklus I siswa yang berhasil mendapat nilai KKM, meningkat dari 18 siswa $(56,25 \%)$ menjadi 22 siswa atau 68,75\% atau terdapat peningkatan sebesar $12,50 \%$. Sedangkan pada siklus II meningkat menjadi 28 siswa yang mendapat nilai diatas $\mathrm{KKM}$ atau $87,50 \%$ atau terdapat peningkatan sebesar $18,75 \%$ dari sebelumnya. Berdasarkan hasil penelitian ini dapat disimpulkan bahwa dengan penerapan metode inquiri dapat meningkatkan hasil belajar mendiskripsikan pelaku ekonomi masyarakat pada siswa kelas VIII A SMP Negeri 7 Sukoharjo Semester I Tahun Pelajaran $2017 / 2018$.
\end{abstract}

Kata kunci: hasil belajar, pelaku ekonomi masyarakat, metode inquiri

\begin{abstract}
This study aims to improve learning outcomes to describe economic actors of society through the method of inquiri on students of class VIII A SMP Negeri 7 Sukoharjo Semester I Lesson Year 2017/2018. The research method using Classroom Action Research which is carried out in two cycles each cycle consists of two meetings, with four stages of research: planning, implementation, observation and reflection. The subject of this research is the students of class VIII A SMP Negeri 7 Sukoharjo academic year 2017/2018. With 32 students. Data collection techniques used are observation, interviews, tests, and documentation. Data analysis used in this research is descriptive qualitative analysis. The results of this study is to improve the learning outcomes to describe the economic actors of society. This is evidenced by the increase in student learning outcomes in the first cycle of students who managed to get KKM scores, increased from 18 students $(56.25 \%)$ to 22 students or $68.75 \%$ or an increase of $12.50 \%$. While in the second cycle increased to 28 students who got a value above the KKM or $87.50 \%$ or an increase of $18.75 \%$ from the previous. Based on the results of this study can be concluded that with the application of inquiri method can improve learning outcomes to describe the economic community in the students of class VIII A SMP Negeri 7 Sukoharjo Semester I Lesson Year 2017/2018.
\end{abstract}

Keywords: learning outcomes, community economic actors, inquiry methods 


\section{PENDAHULUAN}

Masyarakat sebagai pelaku ekonomi sama seperti rumah tangga, yakni bisa berperan sebagai konsumen, produsen, dan distributor. Masyarakat pasti membutuhkan barang dan jasa dalam fungsinya sebagai konsumen. Sebagai produsen, masyarakat membuka usaha sendiri. Ada yang membuka usaha katering, salon, berternak ayam, dan lain sebagainya. Sebagai distributor, ada yang berprofesi sebagai pedagang asongan, penjual bensin eceran, membuka toko, tukang sayur keliling, dan lain-lain. Kegiatan ekonomi yang dilakukan oleh masyarakat dan rumah tangga pada dasarnya sama karena masyarakat merupakan kumpulan rumah tangga.

Oleh karena itu, pembelajaran yang berkaitan dengan masyarakat sebagai pelaku ekonomi yang disampaikan kepada siswa SMP sederajat harus dapat disampaikan dengan metode pembelajaran yang baik dan benar sesuai dengan situasi kelas agar siswa dapat memahami dan mengetahui berbagai peran masyarakat sebagai pelaku ekonomi, baik sebagai konsumen, sebagai produsen, maupun sebagai distributor dalam kegiatan ekonomi tersebut.

Selama ini pembelajaran biasanya hanya disampaikan secara konvensional, dimana guru yang berperan aktif, sementara siswa cenderung pasif. Sikap siswa yang pasif dapat mengurangi keterlibatannya dalam mengikuti proses pembelajaran yang dapat mengakibatkan turunnya minat siswa dalam mengikuti proses pembelajaran. Masalah lain yang muncul adalah rendahnya kemampuan sosial antar siswa. Rendahnya rasa sosial ini akan menimbulkan sifat individualisme pada diri siswa. Hal ini sangat tidak baik jika terus menerus ada di dalam diri siswa. Oleh karena itu, guru harus berperan aktif untuk menumbuhkan rasa sosial di antara siswa. Karena dengan tingginya kemampuan sosial yang dimiliki, para siswa akan lebih mudah berbaur di dalam lingkungan hidupnya. Dalam hal lain yang dapat dikatakan masalah adalah kurangnya rasa percaya diri dalam diri siswa untuk mengemukakan pendapat dan berbicara di depan umum. Banyak siswa yang lebih memilih untuk memendam pendapatnya selama proses pembelajaran. Sebagai pengajar, guru harus membantu siswa menggali kepercayaan diri mereka. Karena dengan adanya rasa percaya diri, siswa akan lebih yakin untuk berbicara di hadapan orang.

Hasil belajar siswa sangat dipengaruhi oleh kualitas pembelajaran yang dilaksanakan di sekolah. Salah satu yang menentukan kualitas pembelajaran adalah penggunaan model pembelajaran yang tepat dengan materi yang diajarkan. Pada kenyataannya banyak sekolah yang kurang memperlihatkan penggunaan model pembelajaran dalam setiap penampilan mengajar. Oleh karena itu, penggunaan metode pengajaran yang tepat terlebih dalam dunia pendidikan sangatlah penting sekali. Pendidikan menjadi motor penggerak bagi keberlangsungan sumber daya manusia yang handal suatu negara, karena pendidikan merupakan cara terbaik untuk meningkatkan kualitas sumber daya manusia suatu bangsa (Tho'in, 2017: 162)

Dengan demikian, suasana pembelajaran menjadi tidak kondusif sehingga siswa menjadi pasif. Kenyataan ini berlaku untuk semua mata pelajaran termasuk mata pelajaran Ilmu Pengetahuan Sosial (IPS). Sardjiyo, dkk mengemukakan, "Ilmu Pengetahuan Sosial (IPS) adalah bidang studi yang mempelajari, menelaah, menganalisis gejala dan masalah 
sosial di masyarakat dengan meninjau dari berbagai aspek kehidupan atau satu perpaduan" (2010: 1.26).

Berdasarkan pendapat di atas dapat disimpulkan bahwa Ilmu Pengetahuan Sosial (IPS) adalah mata pelajaran yang mempelajari kehidupan sosial yang mengkaji seperangkat peristiwa, fakta, konsep, dan generalisasi yang berkaitan dengan isu sosial. Disamping itu, Ilmu Pengetahuan Sosial (IPS) juga merupakan salah satu bidang yang rumit karena luasnya ruang lingkup dan merupakan gabungan dari sejumlah disiplin ilmu seperti ekonomi, sejarah, antropologi, sosiologi, geografi, politik, hukum, budaya dan apa saja yang disebut sipil perlu ditekankan. Adapun tujuan dari Mata pelajaranIlmu Pengetahuan Sosial (IPS) adalah agar peserta didik memiliki kemampuan sebagai berikut:

1. Mengenal konsep-konsep yang berkaitan dengan kehidupan masyarakat dan lingkungan.

2. Memiliki kemampuan dasar untuk berfikir logis dan kritis, menumbuhkan rasa ingin tahu, mampu memecahkan masalah, dan memiliki ketrampilan dalam kehidupan sosial.

3. Memiliki komitmen dan kesadaran terhadap nilai-nilai sosial dan kemanusiaan.

4. Memiliki kemampuan berkomunikasi, bekerja sama dan berkompetensi dalam masyarakat yang majemuk, di tingkat lokal, nasional maupun global.

Upaya peningkatan prestasi belajar siswa tidak terlepas dari berbagai faktor yang mempengaruhinya. Dalam hal ini, diperlukan guru kreatif yang dapat membuat pembelajaran menjadi lebih menarik dan disukai oleh peserta didik. Suasana kelas perlu direncanakan dan dibangun sedemikian rupa dengan menggunakan model pembelajaran yang tepat agar siswa dapat memperoleh kesempatan untuk berinteraksi satu sama lain sehingga pada gilirannya dapat diperoleh prestasi belajar yang optimal. Untuk itu perlu disadari oleh guru bahwa dalam melaksanakan pembelajaran perlu pula diupayakan pembelajaran yang bersifat membangun dan memberikan pengalaman terhadap materimateri yang diberikan.

Keterbatasan waktu yang tersedia menyebabkan guru mengejar target pencapaian kurikulum memilih jalan yang termudah untuk menginformasikan fakta dan konsep, yaitu melalui model ceramah kemudian latihan soal dan siswa memperhatikan penjelasan guru tanpa melakukan aktivitas sehingga siswa pasif. Guru dalam mengajarkan Ilmu Pengetahuan Sosial (IPS) khususnya sub pokok bahasan mendeskripsikan pelaku ekonomi masyarakat kepada siswa kurang melibatkan siswa secara aktif dalam interaksi belajar mengajar sehingga siswa kurang termotivasi dalam belajar. Guru juga kurang melibatkan lingkungan sebagai media sehingga siswa kurang mengenal lingkungan dan tidak dapat memperoleh pemahaman yang berarti. Disaat proses belajar mengajar berlangsung, guru kurang menggunakan model pembelajaran yang bervariasi sehingga hal tersebut dapat menyebabkan siswa jenuh dan kurang aktif.

Penggunaan berbagai macam model pembelajaran dapat memakan waktu yang lebih lama sementara waktu mengajarnya terbatas. Guru juga jarang sekali menggunakan pendekatan pembelajaran ketika sedang mengajarkan materi IPS. Terkait belum optimalnya proses pembelajaran IPS di kelas VIII A SMP Negeri 7 Sukoharjo, maka peneliti berupaya untuk menerapkan metode inquiri sebagai salah satu alternatif pembelajaran bermakna yang bermuara pada pembelajaran yang aktif, kreatif, efektif dan menyenangkan. 
Metode inquiri adalah metode pembelajaran dimana siswa dituntut untuk lebih aktif dalam proses penemuan, penempatan siswa lebih banyak belajar sendiri serta mengembangkan keaktifan dalam memecahkan masalah. Metode mengajar adalah suatu pengetahuan tentang cara-cara mengajar yang dipergunakan oleh seorang guru atau instruktur. Pengertian lain ialah teknik penyajian yang dikuasai guru untuk mengajar atau menyajikan bahan pelajaran kepada siswa di dalam kelas, baik secaraindividual maupun kelompok, agar pelajaran itu dapat diserap, dipahami dan dimanfaatkan oleh siswa dengan baik. Makin baik metode mengajar, makin efektif pula pencapaian tujuan (Ahmadi, 2005 : $52)$.

Proses inquiri adalah suatu proses khusus untuk meluaskan pengetahuan melalui penelitian. Oleh karena itu metode inquiri kadang-kadang disebut juga metode ilmiahnya penelitian. Metode inquiri adalah metode belajar dengan inisiatif sendiri, yang dapat dilaksanakan secara individu atau kelompok kecil. Situasi inquiri yang ideal dalam kelas matematika terjadi, apabila murid-murid merumuskan prinsip matematika baru melalui bekerja sendiri atau dalam grup kecil dengan pengarahan minimal dari guru. Peran utama guru dalam pelajaran inquiri sebagai metoderator (Sutrisman, Tambunan, $1987: 6.39$ ).

Metode inquiri merupakan metode pengajaran yang berusaha meletakan dasar dan mengembangkan cara befikir ilmiah. Dalam penerapan metode ini siswa dituntut untuk lebih banyak belajar sendiri dan berusaha mengembangkan kreatifitas dalam pengembagnaan masalah yang dihadapinya sendiri. Metode mengajar inquiri akan menciptakan kondisi belajar yang efektif dan kundusif, serta mempermudah dan memperlancar kegiatan belajar mengajar (Sudjana, 2004 : 154).

\section{KAJIAN TEORI}

\section{Teori Hasil Belajar Siswa}

Menurut R. Gagne seperti yang dikutip oleh Slameto (2000:78) memberikan dua definisi belajar, yaitu belajar adalah suatu proses untuk memperoleh motivasi dalam pengetahuan, keterampilan, kebiasaan, dan tingkah laku. Belajar adalah penguasaan pengetahuan atau keterampilan yang diperoleh dari instruksi. Menurut Skinner yang dikutip oleh Dimyati dan Mudjiono (2006:93) bahwa belajar merupakan hubungan antara stimulus dan respon yang tercipta melalui proses tingkah laku. M. Sobry Sutikno (2010:35) mengemukakan belajar merupakan suatu proses usaha yang dilakukan oleh seseorang untuk memperoleh suatu perubahan yang baru sebagai hasil pengalamannya sendiri dalam interaksi dengan lingkungannya.

Berdasarkan beberapa pengertian di atas maka dapat penulis simpulkan bahwa belajar adalah perubahan serta peningkatan kualitas dan kuantitas tingkah laku seseorang di berbagai bidang yang terjadi akibat interaksi terus menerus dengan lingkungannya.

Hasil belajar siswa menurut W. Winkel (2004:82) adalah keberhasilan yang dicapai oleh siswa, yakni prestasi belajar siswa di sekolah yang mewujudkan dalam bentuk angka. Hasil belajar adalah pola-pola perbuatan, nilai-nilai, pengertian-pengertian, sikap-sikap, apresiasi dan keterampilan-keterampilan (Suprijono, 2011:5). Hasil belajar adalah hasil yang 
dicapai dalam bentuk angka atau skor setelah tes hasil belajar pada setiap akhir pembelajaran (Dimyati dan Mujiono, 2006:24).

Definisi di atas dapat disimpulkan bahwa hasil belajar adalah prestasi belajar yang dicapai siswa dalam proses kegiatan belajar mengajar dengan membawa suatu perubahan dan pembentukan tingkah laku seseorang. Untuk menyatakan bahwa suatu proses belajar dapat dikatakan berhasil, setiap guru memiliki pandangan masing-masing sejalan dengan filsafatnya. Namun untuk menyamakan persepsi sebaiknya kita berpedoman pada kurikulum yang berlaku saat ini yang telah disempurnakan, antara lain bahwa suatu proses belajar mengajar tentang suatu bahan pembelajaran dinyatakan berhasil apabila tujuan pembelajaran khususnya dapat dicapai.

Dalam rangka mengetahui tercapai tidaknya tujuan pembelajaran khusus, guru perlu mengadakan tes formatif pada setiap menyajikan suatu bahasan kepada siswa. Penilaian formatif ini untuk mengetahui sejauh mana siswa telah menguasai tujuan pembelajaran khusus yang ingin dicapai. Fungsi penelitian ini adalah untuk memberikan umpan balik pada guru dalam rangka memperbaiki proses belajar mengajar dan melaksanakan program remedial bagi siswa yang belum berhasil. Karena itulah, suatu proses belajar mengajar dinyatakan berhasil apabila hasilnya memenuhi tujuan pembelajaran khusus dari bahan tersebut.

Hasil belajar yang dicapai oleh siswa di sekolah merupakan salah satu ukuran terhadap penguasaan materi pelajaran yang disampaikan. Peran guru dalam menyampaikan materi pelajaran dapat mempengaruhi hasil belajar siswa. Faktor-faktor yang mempengaruhi hasil belajar siswa penting sekali untuk diketahui, artinya dalam rangka membantu siswa mencapai hasil belajar yang seoptimal mungkin. Hasil belajar akan semakin maksimal jika semua unsur masyarakat menyadari pentingnya pendidikan, karena pendidikan cara perbaik memperbarui kualitas bangsa (Tho'in, 2017).

Hasil belajar yang dicapai siswa dipengaruhi oleh dua faktor baik yang bersifat mendorong atau menghambat, demikian pula dalam belajar. Faktor yang mempengaruhi prestasi atau hasil belajar siswa yakni faktor dari dalam diri siswa (interen) dan faktor yang datang dari luar (eksteren). Ahmadi (1998:72) mengemukakan untuk mencapai prestasi belajar siswa sebagaimana yang diharapkan, maka perlu diperhatikan beberapa faktor yang mempengaruhinya antara lain faktor yang terdapat dalam diri siswa (faktor intern) dan faktor yang berasal dari luar diri siswa (faktor ekstern).

\section{Pelaku Ekonomi Masyarakat}

Selain rumah tangga keluarga, masyarakat juga merupakan salah satu dari pelaku ekonomi. Masyarakat merupakan kumpulan dari rumah tangga. Masyarakat sebagai pelaku ekonomi sama seperti rumah tangga, yakni berperan sebagai podusen, distributor dan konsumen. Untuk penjelasan lebih lanjut, akan dijelaskan satu per satu.

1. Masyarakat sebagai produsen

Masyarakat sebagai produsen mencakup berbagai bentuk kegiatan masyarakat yang dapat menghasilkan pendapatan, misalnya dapat berupa kegiatan usaha, berdagang, bercocok tanam, beternak, dan sebagainya. Sistem ekonomi Indonesia memiliki acuan 
yang jelas, yaitu Undang-Undang Dasar 1945. Maka dari itu sistem ekonomi bukanlah pasar bebas maupun perencanaan sentral, melainkan sistem ekonomi Indonesia mendasarkan pada ekonomi kerakyatan. Dalam sistem ekonomi kerakyatan masyarakat memegang peranan aktif dalam kegiatan ekonomi, sedangkan pemerintah menciptakan iklim yang sehat bagi pertumbuhan dan perkembangan dunia usaha. Sistem ekonomi kerakyatan dapat didefinisikan sebagai pengaturan kehidupan ekonomi yang memungkinkan seluruh potensi masyarakat untuk berpartisipasi aktif dalam berbagai kegiatan ekonomi. Kesejahteraan rakyat yang meningkat, merata, dan berkeadilan merupakan tujuan utama demokrasi ekonomi kerakyatan. Salah satu pilar penyangga ekonomi kerakyatan adalah usaha informal yang berkembang dalah kehidupan masyarakat.

2. Masyarakat sebagai konsumen

Masyarakat sebagai konsumen memerlukan barang dan jasa bagi kelangsungan hidup masyarakat. Masyarakat adalah pengguna (konsumen) "public goods" atau produkproduk umum, seperti jalan raya, jembatan, rumah sakit, sekolah, dan lain-lain. Penggunaan public goods yang pada umumnya disediakan oleh pemerintah pusat maupun daerah, bertujuan untuk memenuhi kebutuhan hidupnya. Masyarakat yang tidak memiliki pekerjaan atau pengangguran merupakan bentuk kehidupan yang hanya melakukan kegiatan konsumsi saja, sehingga sering menimbulkan masalah di masyarakat. Berbagai tindak kejahatan dilakukan semata-mata karena untuk memenuhi kegiatan konsumsi. Di mana orang memiliki banyak kebutuhan, tetapi tidak memiliki pekerjaan yang dapat menghasilkan pendapatan bagi pemenuhan kebutuhan tersebut.

Oleh karena itu, penting bagi setiap orang sejak dini tertanam sikap untuk mampu berproduksi dan bukan hanya melakukan konsumsi saja. Di samping itu berkaitan dengan kegiatan konsumsi, perlu dilandasi sikap mental untuk bisa mengukur kemampuan diri, sehingga tidak besar pasak daripada tiang.

3. Masyarakat sebagai distributor

Masyarakat sebagai distributor diwujudkan dalam bentuk terjadinya penyaluran proses penyaluran barang dan jasa dari produsen ke konsumen. Lalu lintas perdagangan dan transportasi yang membawa barang-barang pemenuhan kebutuhan dalam kehidupan masyarakat merupakan bentuk kegiatan distribusi yang berlangsung di masyarakat. Kelancaran arus distribusi yang berlangsung di masyarakat dapat kita amati dari lancartidaknya proses transportasi barang kebutuhan dari satu kota ke kota yang lain. Salah satu faktor yang memicu terjadinya kelangkaan barang antara lain disebabkan ketidaklancaran proses distribusi. Hal ini sering terjadi di daerah-daerah yang sulit transportasinya.

\section{Metode Inquiri}

Kata inkuiri sering juga dinamakan heuriskin yang berasal dari bahasa yunani, yang memiliki arti saya menemukan. Metode inkuiri berkaitan dengan aktivitas pencarian pengetahuan atau pemahaman untuk memuaskan rasa ingin tahu sehingga siswa akan menjadi pemikir kreatif yang mampu memecahkan masalah. Hal ini sejalan dengan pendapat Sanjaya (2006: 196) bahwa "Metode inkuiri adalah suatu metode pembelajaran yang 
menekankan pada proses berpikir secara kritis dan analitis untuk mencari dan menemukan sendiri jawaban dari suatu permasalahan yang dipertanyakan".

Sementara itu menurut Sagala (2004:34) yang mendefenisikan metode inkuiri sebagai berikut: Metode inkuiri merupakan metode pembelajaran yang berupaya menanamkan dasar-dasar berfikir ilmiah pada diri siswa yang berperan sebagai subjek belajar, sehingga dalam proses pembelajaran ini siswa lebih banyak belajar sendiri, mengembangkan kreativitas dalam memecahkan masalah. Sedangkan Piaget (Mulyasa, 2008:108) mendefenisikan metode inkuiri sebagai berikut: Metode inkuiri adalah metode yang mempersiapkan siswa pada situasi untuk melakukan eksperimen sendiri secara luas agar melihat apa yang terjadi, ingin melakukan sesuatu, mengajukan pertanyaan-pertanyaan, dan mencari jawabannya sendiri, serta menghubungkan penemuan yang satu dengan penemuan yang lain, membandingkan apa yang ditemukannya dengan yang ditemukan peserta didik lain. Sedangkan menurut Aziz (2007: 92) memiliki defenisi lain mengenai pengertian metode inkuiri sebagaimana yang tertulis sebagai berikut: Metode inkuiri adalah metode yang menempatkan dan menuntut guru untuk membantu siswa menemukan sendiri data, fakta dan informasi tersebut dari berbagai sumber agar dengan kegiatan itu dapat memberikan pengalaman kepada siswa. Pengalaman ini akan berguna dalam menghadapi dan memecahkan masalah-masalah dalam kehidupannya.

Berdasarkan beberapa pendapat para ahli yang telah dikemukakan sebelumnya, maka dapat diambil kesimpulan bahwa metode inkuiri adalah metode yang memberi kesempatan kepada siswa untuk terlibat secara aktif dalam proses pembelajaran melalui percobaan maupun eksperimen sehingga melatih siswa berkreativitas dan berpikir kritis untuk menemukan sendiri suatu pengetahuan yang pada akhirnya mampu menggunakan pengetahuannya tersebut dalam memecahkan masalah yang dihadapi. Dalam penerapannya di bidang pendidikan, ada beberapa jenis metode inkuiri. Sebagaimana yang dikemukakan oleh Sund and Trowbridge (Mulyasa, 2006: 109) bahwa Jenis-jenis metode inkuiri adalah sebagai berikut:

a. Inkuiri terpimpin (Guide inquiry), inkuiri terpimpin digunakan terutama bagi siswa yang belum mempunyai pengalaman belajar dengan metode inkuiri. Dalam hal ini guru memberikan bimbingan dan pengarahan yang cukup luas. Dalam pelaksanaannya, sebagian besar perencanaan dibuat oleh guru dan para siswa tidak merumuskan permasalahan.

b. Inkuiri bebas (Free inkuiry), pada inkuiri bebas siswa melakukan penelitian sendiri bagaikan seorang ilmuwan. Pada pengajaran ini, siswa harus dapat mengidentifikasikan dan merumuskan berbagai topik permasalahan yang hendak diselidiki. Metodenya adalah inquiry role approach yang melibatkan siswa dalam kelompok tertentu, setiap anggota kelmpok tugas memiliki tugas sebagai, misalnya koordinator kelompok, pembimbing teknis, pencatatan data, dan pengevaluasi proses.

c. Inkuiri bebas yang dimodifikasi (Modified free inquiry), pada inkuiri ini guru memberikan permasalahan atau problem dan kemudian siswa diminta untuk memecahkan permasalahan tersebut melalui pengamatan, eksplorasi, dan prosedur penelitian. 
Menurut Sanjaya (2006:197) Ada beberapa hal yang menjadi karakteristik utama dalam metode pembelajaran inkuiri, yaitu:

a. Metode inkuiri menekankan kepada aktivitas siswa secara maksimal untuk mencari dan menemukan. Dalam proses pembelajaran, siswa tidak hanya berperan sebagai penerima pelajaran melalui penjelasan guru secara verbal, tetapi mereka berperan untuk menemukan sendiri inti dari materi pelajaran itu sendiri.

b. Seluruh aktivitas yang dilakukan siswa diarahkan untuk mencari dan menemukan jawaban sendiri dari sesuatu yang dipertanyakan, sehingga diharapkan dapat menumbuhkan sikap percaya diri (self belief). Dengan demikian, metode pembelajaran inkuiri menempatkan guru bukan sebagai sumber belajar akan tetapi sebagai fasilitator dan motivator belajar siswa.

c. Tujuan dari penggunaan metode inkuiri dalam pembelajaran adalah mengembangkan kemampuan berpikir secara sistematis, logis dan kritis atau mngembangkan kemampuan intelektual sebagai bagian dari proses mental. Dengan demkian, dalam metode inkuiri siswa tidak hanya dituntut agar menguasai materi pelajaran, akan tetapi bagaimana mereka dapat menggunakan kemampuan yang dimilikinya secara optimal.

\section{METODE}

Metode penelitian menggunakan penelitian tindakan kelas (PTK) yang dilaksanakan dalam dua siklus setiap siklus terdiri dua kali pertemuan, dengan empat tahap penelitian: perencanaan, pelaksanaan, pengamatan dan refleksi. Subjek penelitian ini adalah siswa-siswi kelas VIII A SMP Negeri 7 Sukoharjo tahun ajaran 2017/2018. Dengan jumlah 32 siswa. Teknik pengumpulan data yang digunakan adalah observasi, wawancara, tes, dan dokumentasi. Analisis data yang digunakan dalam penelitian ini adalah analisis deskriptif kualitatif.

\section{PEMBAHASAN}

Setelah peneliti melaksanakn tindakan penelitian melalui penerapan metode inquiri, secara empiris diperoleh data peningkatan hasil belajar IPS siswa kelas VIII A SMP Negeri 7 Sukoharjo Kecamatan Sukoharjo, Kabupaten Sukoharjo semester I Tahun Pelajaran 2017/2018 dari kondisi awal, siklus I dan siklus II sebagai berikut.

Tabel 1. Peningkatan Prestasi Belajar Siswa

\begin{tabular}{|l|c|c|c|}
\hline \multicolumn{1}{|c|}{ Uraian } & Kondisi awal & Siklus I & Siklus II \\
\hline Tindakan & Belum menerapkan & Sudah menerapkan & Sudah menerapkan \\
Pembelajaran & metode inquiri & metode inquiri & metode inquiri \\
\hline Nilai terendah & 60 & 60 & 70 \\
Nilai tertinggi & 80 & 90 & 90 \\
Nilai rata-rata & 70 & 75 & 85 \\
KKM & 75 & 75 & 75 \\
Ketuntasan & 18 siswa $(56,25 \%)$ & 22 siswa $(68,75 \%)$ & 28 siswa $(87,50 \%)$ \\
\hline
\end{tabular}


Melalui penerapan metode inquiri dapat meningkatkan hasil belajar IPS materi mendiskripsikan pelaku ekonomi masyarakat. Pada kondisi awal peneliti belum menerapkan metode inquiri. Nilai rata-rata siswa kelas VIII A adalah 70, masih di bawah nilai KKM yang ditetapkan yaitu 75. Nilai tertinggi siswa 80, nilai terendah 60 dan jumlah siswa kelas VIII A yang mencapai nilai KKM hanya 18 siswa $(56,25 \%)$ dari total 32 siswa kelas VIII A SMP Negeri 7 Sukoharjo.

Pada siklus I guru peneliti sudah menerapkan metode inquiri dalam pembelajaran IPS materi mendiskripsikan pelaku ekonomi masyarakat. Nilai rata-rata hasil belajar IPS siswa kelas VIII A SMP Negeri 7 Sukoharjo adalah 75, nilai tertinggi 90 dan nilai terendah adalah 60. Sedangkan jumlah siswa yang mencapai nilai KKM sebanyak 22 siswa $(68,75 \%)$ dari total 32 siswa kelas VIII A SMP Negeri 7 Sukoharjo.

Pada siklus II, nilai rata-rata hasil belajar IPS siswa kelas VIII A SMP Negeri 7 Sukoharjo adalah 85, nilai tertinggi 90 dan nilai terendah 70. Jumlah siswa yang mencapai nilai KKM sebanyak 28 siswa $(87,50 \%)$ dari total 32 siswa kelas VIII A SMP Negeri 7 Sukoharjo.

Jadi, melalui penerapan metode inquiri dapat meningkatkan hasil belajar IPS dari kondisi awal nilai rata-rata 70 dengan ketuntasan 56,25\% ke kondisi akhir pada siklus II nilai rata-rata 85 dengan ketuntasan $87,50 \%$ pada siswa kelas VIII A SMP Negeri 7 Sukoharjo semester I Tahun Pelajaran 2017/2018.

\section{SIMPULAN}

Hipotesis menyatakan diduga melalui penerapan metode inquiri dapat meningkatkan hasil belajar IPS materi mendiskripsikan pelaku ekonomi masyarakat pada siswa kelas VIII A SMP Negeri 7 Sukoharjo semester I Tahun Pelajaran 2017/2018. Dari data empirik menyatakan melalui penerapan metode inquiri dapat meningkatkan hasil belajar IPS materi mendiskripsikan pelaku ekonomi masyarakat dari kondisi awal nilai rata-rata 70 dengan ketuntasan $56,25 \%$ ke kondisi akhir pada siklus II nilai rata-rata 85 dengan ketuntasan 87,50\% pada siswa kelas VIII A SMP Negeri 7 Sukoharjo semester I Tahun Pelajaran $2017 / 2018$.

Sehingga dapat disimpulkan bahwa melalui penerapan metode inquiri dapat meningkatkan hasil belajar IPS materi mendiskripsikan pelaku ekonomi masyarakat pada siswa kelas VIII A SMP Negeri 7 Sukoharjo semester I Tahun Pelajaran 2017/2018.

\section{DAFTAR PUSTAKA}

Ahmadi, Abu. 1998. Psikologo Pendidikan. Jakarta : Rineka Cipta

Dimyati dan Mudjiono. 2006. Belajar dan Pembelajaran. Jakarta: Rineka Cipta

E. Mulyasa. 2008. Menjadi Guru Profesional Menciptakan Pembelajaran Kreatif dan Menyenangkan. Bandung : PT. Remaja Rosdakarya. 
M. Sobry Sutikno. 2010. Strategi Belajar Mengajar Melalui Penanaman Konsep Umum \& Konsep Islami. Refika Aditama: Bandung.

Nasution. 1995. Metode Research. Jakarta : PT. Bumi Aksara

Ngalim Purwanto. 1986. Psikologi Pendidikan. Bandung: PT Remaja Rosdakarya.

Sagala. 2004. Konsep Dan Makna Pembelajaran. Bandung: Alfabeta.

Sanjaya, Wina. 2009. Penelitian Tindakan Kelas. Jakarta: Kencana Prenada Media Group

Sardjiyo, dkk. 2009. Pendidikan IPS di SD. Universitas Terbuka. Jakarta

Slameto. 2000. Belajar dan Faktor-faktor yang mempengaruhinya. Rineka Cipta,Jakarta

Sudjana, Nana. 2009. Dasar-dasar Proses Belajar Mengajar. Bandung: Sinar Baru Algensindo.

Suprijono, Agus. (2011). Model Pembelajaran Kooperatif. Jakarta: Bumi Aksara

Sutrisman dan G. Tambunan. 1987. Pengajaran Matematika. Jakarta: Penerbit Karunika Universitas Terbuka..

Teti Sobari. (2006). Pembelajaran Kooperatif. Jakarta: PT. Bumi Aksara

Tho'in, M. (2017). Pembiayaan Pendidikan Melalui Sektor Zakat. Al-Amwal: Jurnal Ekonomi dan Perbankan Syari'ah, 9(2).

Winkel, W. S. (2004). Psikologi Pendidikan dan Evaluasi Belajar. Jakarta: PT. Gramedia Pustaka Utama. 